\title{
ENDOSCOPIC FOLLOW-UP OF CYANOACRYLATE OBLITERATION OF GASTRIC VARICES
}

\author{
Fernanda Prata MARTINS, Erika Pereira de MACEDO, Gustavo Andrade de PAULO, \\ Frank Shigueo NAKAO, José Celso ARDENGH and Angelo Paulo FERRARI
}

\begin{abstract}
Bleeding from gastric varices is a life-threatening condition. We report our experience with cyanoacrylate injection. Twenty three patients with portal hypertension and gastric varices underwent intra-variceal injection of a cyanoacrylate/lipiodol solution (1:1). Study endpoint was variceal obliteration. Mean follow-up was 25.3 months. Variceal obliteration was achieved in $87 \%$ of patients. Recurrence occurred in one patient (4.3\%) and rebleeding in another case (4.3\%). Mild abdominal pain was described in $13 \%$ of patients. Overall mortality was $21.7 \%$ and rebleeding related mortality rate was $4.3 \%$. Our results confirm that cyanoacrylate injection is effective and safe to eradicate gastric varices.
\end{abstract}

HEADINGS - Esophageal and gastric varices. Cyanoacrylates. Follow-up studies.

\section{INTRODUCTION}

Gastric varices (GV) are described in approximately $20 \%$ of patients with portal hypertension and about $25 \%$ $40 \%$ will bleed during lifetime ${ }^{(2,3)}$. The incidence of gastric variceal bleeding is lower compared to esophageal varices however, usually more severe, more difficult to control and associated with higher mortality $(25 \%-45 \%)^{(3)}$.

Gastric varices were classified by SARIN et al.(3) When associated with esophageal varices (GOV) are classified in type 1 (GOV1), if distributed along the lesser curvature or type 2 (GOV2) if distributed along the fundus. GV can also be isolated in the stomach (IGV), located in the fundus (IGV type 1) or at ectopic sites (IGV type 2).

Frequency and severity of bleeding from GVs depend on their type and location. IGV1 and GOV2 bleed more often and more massively ( $78 \%$ and $54 \%$, respectively $)^{(4)}$ Due to their large size, deeper submucosal location and extensive distribution, it is uncommon to eradicate GV with standard endoscopic therapies ${ }^{(2)}$.

Variceal obliteration using cyanoacrylate provides the best therapeutic option. After injection into the varix, cyanoacrylate rapidly polymerizes in contact with blood, becoming a hard ('plastic') substance that occludes variceal lumen ${ }^{(2)}$.

Cyanoacrylate endoscopic injection was first described for the treatment of GV by SOEHENDRA et al. ${ }^{\left({ }^{6}\right)}$, in 1986, and its benefit is now widely recognized. Success rate in controlling active variceal bleeding has been reported between $89 \%-100 \%$ and recurrence rate below $30 \%(2,4)$.

\section{METHODS}

Consecutive patients with portal hypertension and Sarin IGV1 or GOV2 were prospectively included. Patients with no history of bleeding, but high risk varices ${ }^{(3)}$ defined as a varix $\geq 2 \mathrm{~cm}$ in diameter, presence of endoscopic stigmata (red wale marks) or secondary GV were also enrolled in the study.

Patients with associated esophageal varices were first submitted to endoscopic treatment for esophageal varices. Age less than 18 years, pregnancy and uncompensated cirrhosis were exclusion criteria. All patients have signed an informed consent for the endoscopic procedure.

Endoscopic procedures were performed using a regular videoendoscope and a 21 Gauge needle. Gastric variceal injection was performed in the U-turn position. The injection needle was initially flushed with lipiodol and then a mixture of cyanoacrylate/lipiodol (1:1) was injected into the varix. Lipiodol was again injected to flush all the solution out of the needle.

Follow-up endoscopy was performed at 3-month interval until endoscopic obliteration was achieved and then reevaluation at 6-month interval followed by annual control (Figure 1).

At each endoscopy, evidence of GV was recorded. Varix patency was tested by visual control and 'blunt touching'. When the varix was found to be soft, additional

"Universidade Federal de São Paulo" - UNIFESP, São Paulo, SP, Brazi

Correspondence: Dr. Fernanda Prata Martins - Al. Ministro Rocha Azevedo, 976 - apt. 71 - 01410-002 - São Paulo, SP, Brasil. Email: fernandaprata@terra.com.br 


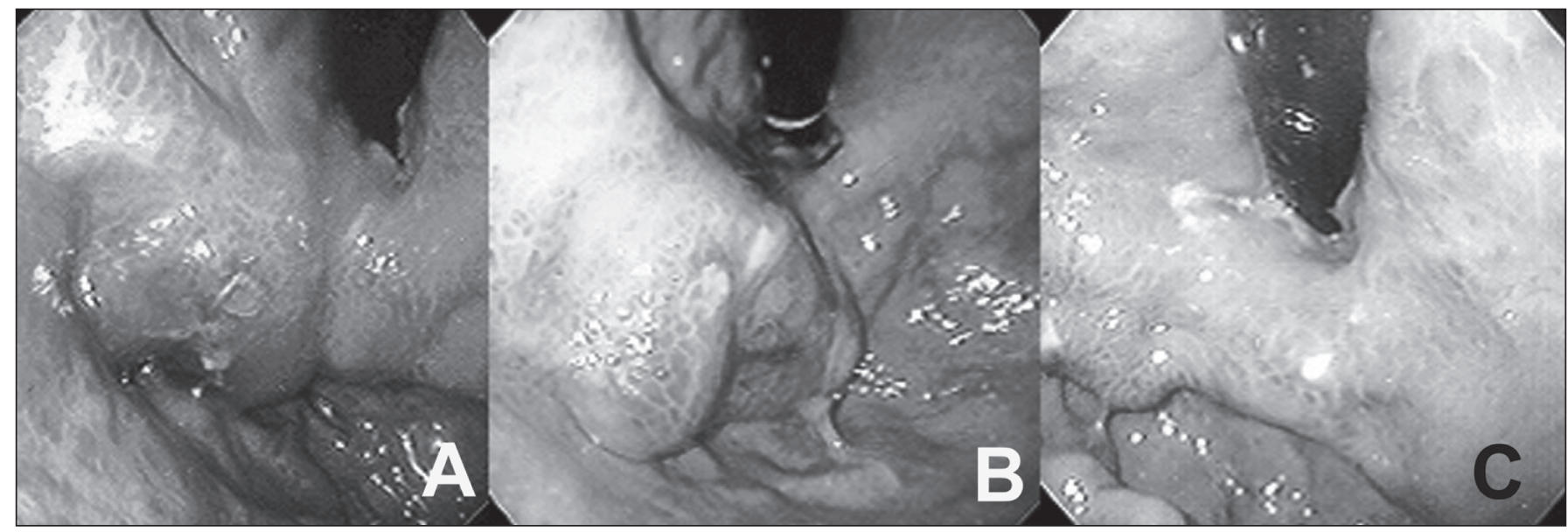

FIGURE 1. Endoscopic view of cyanoacrylate injection therapy: A) initial view after injection; B) extrusion of part of the glue; C) 6 months after injection, endoscopy showing no evidence of gastric varix

cyanoacrylate/lipiodol injection was performed. It is important to remember that a varix occluded with cyanoacrylate may remain visible for a long period, but presents as a firm structure during endoscopic 'touching'.

The number of sessions and mean variceal time obliteration, follow-up, complications and mortality rate were observed. Bleeding occurring from GVs before the upcoming session was considered rebleeding. Rebleeding was managed endoscopically. Recurrence of GVs was defined as reappearance of varices after initial successful obliteration.

\section{RESULTS}

A total of 23 patients with GV were enrolled in the study. Three patients had IGV1, whereas the remaining 20 had GOV2. Results are summarized in Table 1.

TABLE 1. Results of elective endoscopic treatment for gastric varices with cyanoacrylate injection

\begin{tabular}{lc}
\hline Parameters & \\
\hline Number of patients & $23(100 \%)$ \\
Varix obliteration & $20(87 \%)$ \\
Number of sessions & $1.8(\mathrm{SD} 0.9)$ \\
Mean cyanoacrylate/lipiodol volume injected & $2.0 \mathrm{~mL}$ \\
Mean follow-up & $25.3(\mathrm{SD} 16.2)$ months \\
Rebleeding rate & $1(4.3 \%)$ \\
Recurrence rate & $1(4.3 \%)$ \\
Minor complications rate & $3(13 \%)$ \\
Major complications rate & $1(4.3 \%)$ \\
Overall mortality rate & $5(21.7 \%)$ \\
Bleeding related mortality rate & $1(4.3 \%)$
\end{tabular}

SD: Standard deviation

There were 15 men and 8 women with a mean age of 53.4 years (SD 12.5). The most common cause of portal hypertension was cirrhosis due to hepatitis $\mathrm{C}$ virus (HCV) (10), followed by alcohol (4), HCV and alcohol (3), hepatitis B virus (2) and 4 patients had schistossomiasis.
Most patients (19/23) had a history of upper gastrointestinal bleeding within several weeks of enrollment, but none had active bleeding at endoscopy. Four patients had no prior GI bleeding, but had high-risk varices.

Cyanoacrylate injection was successfully performed in all patients. The mean follow-up period was 25.3 months (SD 16.2), ranging from 2 to 63 months.

Gastric variceal obliteration was achieved in $87 \%$ of patients (20/23). Mean number of sessions to achieve obliteration was 1.8 (SD 0.9). The average volume of cyanoacrylate injected was $1.0 \mathrm{~mL}$ per patient ( $2 \mathrm{~mL}$ of the diluted solution). Gastric variceal obliteration was achieved with a single injection in $52.2 \%(12 / 23)$ of patients.

Three patients (13\%) reported mild and transient abdominal discomfort. No fever was referred and no post injection ulcers were noted.

One patient (4.3\%) developed a recurrent gastric varix 20 months after index therapy. In one case (4.3\%), spurting bleeding developed after puncture of the non-bleeding varix and additional injection was required to achieve hemostasis.

Overall mortality rate was $21.7 \%(5 / 23)$, but only one case (4.3\%) was related to gastric variceal rebleeding. Rebled occurred 2 months after index injection, before variceal obliteration could be achieved. He was admitted to another hospital and despite endoscopic sclerotherapy with ethanolamine he died before discharge. The remaining two deaths were secondary to liver failure.

There were no other major complications. We have not experienced damage to the endoscope or clogging of the accessory channel during the study.

\section{DISCUSSION}

The classification proposed by SARIN et al. ${ }^{(3)}$ differentiates gastroesophageal varices from isolated GV. This distinction is important because therapeutic results may differ according to variceal location and morphology. In our study we included 
only fundic location (IGV1 and GOV2) with nodular or pseudo tumoral aspect.

Large fundic varices bleed more often than small ones $(53 \% \text { versus } 6.99 \%, P<0.001)^{(4)}$. Moreover, GVs are known to bleed more severely than esophageal varices, with cumulative mortality in cirrhotic patients reaching $52 \%$ at the end of the first year ${ }^{(4)}$. Therefore, an effective therapy for patients with GV is of major importance.

Injection of cyanoacrylate in order to achieve variceal obliteration is the first line therapy for GV. Sclerotherapy and band ligation do not lead to complete thrombosis of the vessel $^{(4,5)}$. Other less effective therapeutic options include: thrombin injection, detachable snares and balloon-occluded retrograde trans-venous obliteration. Trans-jugular intra-hepatic portosystemic shunt is an option capable to control acute bleeding and prevent rebleeding.

Sclerosant agents (ethanolamine and alcohol) are not as effective as cyanoacrylate, neither in arresting acute bleeding nor obliterating the varix, possibly because of the larger caliber and higher blood flow ${ }^{(4)}$. Also, due to variceal size, sclerotherapy requires a significant amount of sclerosant to be injected, which can be associated with several complications, including ulcer formation with possible secondary bleed ${ }^{(4)}$. Band ligation is also less effective, associated with higher rebleeding, morbidity and mortality rates.

Cyanoacrylate is a watery solution, which polymerizes and precipitates after a few seconds upon contact with blood leading to variceal obliteration. To prevent cyanoacrylate from solidifying too quickly, it is necessary to add an oily contrast agent: lipiodol $^{\circledR(5)}$. There is currently no standardization of equipment or injection technique. Dilution has varied among studies from undiluted to $2: 1^{(2)}$. As most investigators we have used the dilution ratio $1: 1$ in a catheter previously filled with lipiodol.

Gastric varices obliteration seems to be achieved in a shorter period when cyanoacrylate is used ${ }^{(2,4)}$. In our study, variceal occlusion was achieved after a mean of 1.8 sessions, consistent with the current literature. Cyanoacrylate also has the advantage of small volume injection, although the amount of cyanoacrylate required to achieve obliteration may vary according to variceal size ${ }^{(2)}$.
In a randomized study with 37 patients SARIN et al. ${ }^{(4)}$ have demonstrated that cyanoacrylate was more effective than alcohol sclerotherapy $(100 \%$ versus $44 \%, P<0.05)$ in obliterating varices. Obliteration was also achieved in a significantly shorter period of time, with smaller volume and also better control of active bleeding ( $89 \%$ versus $62 \%)$.

Minor complications have been described after cyanoacrylate injection, including fever, bacteremia and mucosal ulcer in up to $21.2 \%$ of patients ${ }^{(2,4,5)}$.

Major complications such as rebleeding and embolism are $\operatorname{rare}^{(2,5)}$. Embolic events including pulmonary embolism, splenic infarction, cerebral stroke and portal vein embolism have been described. The amount of cyanoacrylate injected may play a role in the embolic complications ${ }^{(5)}$. Although one patient rebled before variceal obliteration, we have not found any other major complication.

Gastric variceal recurrence rate is described ranging from $0 \%-30 \%$ and recurrent bleeding is described in up to $31 \%$ of patients ${ }^{(2,4)}$. During the follow-up, one case $(4.3 \%)$ of variceal recurrence and one rebleeding (4.3\%) occurred in our study.

In studies evaluating cyanoacrylate therapy, mortality ranges from $2 \%-40 \%$, over follow-up periods of 1 to 3 years, with bleeding related mortality reaching $10 \%{ }^{(2,5)}$. Our overall mortality rate was $21.7 \%$, with only $4.3 \%$ related to gastric variceal bleeding in a mean follow-up of 25.3 months.

Treatment of non-bleeding primary varices remains controversial ${ }^{(2)}$. Our choice to prophylatically treat patients with high risk GV was based on the evidence that such patients have been shown to be at higher risk for serious bleeding ${ }^{(1)}$. KIM et al. ${ }^{(1)}$ have demonstrated cumulative bleeding rates of $16 \%, 36 \%$ and $44 \%$ at 1,3 and 5 years, respectively. In our opinion, such a high bleeding risk justifies prophylactic therapy for GV.

\section{CONCLUSION}

Even considering the restriction of our small number of patients, our results support the use of cyanoacrylate to obliterate GV. Endoscopic injection of cyanoacrylate was effective and safe in order to achieve gastric variceal obliteration.

Martins FP, Macedo EP, Paulo GA, Nakao FS, Ardengh JC, Ferrari AP. Seguimento endoscópico da erradicação de varizes gástricas com cianoacrilato. Arq Gastroenterol. 2009;46(1): 81-4.

RESUMO - Sangramento por varizes gástricas é grave. Relato de experiência com injeção de cianoacrilato. Vinte e três pacientes com hipertensão portal e varizes gástricas foram tratados com injeção intravasal de solução de cianoacrilato/lipiodol (1:1). O objetivo do estudo foi alcançar obliteração da variz. O tempo médio de acompanhamento foi 25,3 meses. Obliteração foi atingida em $87 \%$ dos pacientes. Recidiva foi observada em um (4,3\%) e ressangramento em outro caso (4.3\%). Dor abdominal ocorreu em 13\% dos pacientes. A mortalidade global foi de $21,7 \%$ e 4,3\% relacionada ao ressangramento. Estes resultados confirmam a injeção de cianoacrilato como efetiva e segura na erradicação das varizes gástricas.

DESCRITORES - Varizes esofágicas e gástricas. Cianoacrilatos. Seguimentos 


\section{REFERENCES}

1. Kim T, Shijo H, Kokawa H, Tokumitsu H, Kubara K, Ota K, Akiyoshi N, Iida T, Yokoyama M, Okumura M. Risk factors for hemorrhage from gastric fundal varices. Hepatology. 1997;25:307-12

2. Rengstorff DS, Binmoeller KF. A pilot study of 2-octyl cyanoacrylate injection for treatment of gastric fundal varices in humans. Gastrointest Endosc. 2004;59:553-8.

3. Sarin SK, Lahoti D, Saxena SP, Murthy NS, Makwana UK. Prevalence, classification and natural history of gastric varices: a long-term follow-up study in 568 portal hypertension patients. Hepatology. 1992;16:1343-9.
4. Sarin SK, Jain AK, Jain M, Gupta R. A randomized controlled trial of cyanoacrylate versus alcohol injection in patients with isolated fundic varices. Am J Gastroenterol. 2002;97:1010-5.

5. Seewald S, Sriram PV, Naga M, Fennerty MB, Boyer J, Oberti F, Soehendra N. Cyanoacrylate glue in gastric variceal bleeding. Endoscopy. 2002;34:926-32.

6. Soehendra N, Nam VC, Grimm H, Kempeneers I. Endoscopic obliteration of large esophagogastric varices with bucrylate. Endoscopy. 1986;18:25-6.

Recebido em 30/5/2008 Aprovado em 20/6/2008 